Katsuya Mikawa MD, Kahoru Nishina MD, Nobuhiro Maekawa MD, Migiwa Asano MD, Hidefumi Obara MD

\title{
Oral clonidine premedication reduces vomiting in children after strabismus surgery
}

This is a prospective randomized double-blind trial conducted to determine whether preoperative orally administered clonidine causes or potentiates postoperative vomiting in 140 children (3-12 yr) undergoing strabismus surgery. They were all inpatients and classified randomly into four groups ( $n=35$ each); placebo (control), diazepam $0.4 \mathrm{mg} \cdot \mathrm{kg}^{-1}$, clonidine 2 $\mu \mathrm{g} \cdot \mathrm{kg}^{-1}$, and clonidine $4 \mu \mathrm{g} \cdot \mathrm{kg}^{-1}$. These agents were administered 93-112 min (mean: $100 \mathrm{~min}$ ) before the anticipated time of induction of anaesthesia. All children received inhalational anaesthesia with halothane and nitrous oxide in oxygen. Muscle relaxation in all patients was obtained with vecuronium and residual neuromuscular blockade was antagonized with neostigmine and atropine before tracheal extubation. Diclofenac suppository was prescribed to prevent postoperative pain. No opioids or postoperative antiemetics were administered. All children remained in hospital for two days postoperatively. The incidence and frequency of vomiting were compared in the groups with Kruskall-Wallis Rank test. Clonidine $4 \mathrm{\mu g} \cdot \mathrm{kg}^{-1}$ caused a lower incidence and frequency of vomiting than did placebo and diazepam (incidence and frequency: $11 \%$ and $1,37 \%$ and 3 , and $34 \%$ and 2 in clonidine $4 \mu \mathrm{g} \cdot \mathrm{kg}^{-1}$, placebo, and diazepam, respectively; $P<0.05$ for clonidine $4 \mu \mathrm{g} \cdot \mathrm{kg}^{-1} \mathrm{vs}$ placebo and diazepam). However, lowdase clonidine was ineffective. These data suggest that preanaesthetic medication with clonidine $4 \mu \mathrm{g} \cdot \mathrm{kg}^{-1}$ may be useful for preventing emesis following strabismus surgery. This prop-

\section{Key words}

ANAESTHESIA: paediatric;

PREMEDICATION: diazepam, clonidine;

SYMPATHETIC NERVOUS SYSTEM: alpha-adrenergic agonist, clonidine;

voMITING: antiemetics, nausea.

From the Department of Anaesthesiology, Kobe University School of Medicine, Kusunoki-cho 7, Chuo-ku, Kobe 650, Japan.

Address correspondence to: Dr. K. Mikawa.

Accepted for publication 30th June, 1995. erty of clonidine indicates that it may be superior to other sedative premedicants such as diazepam and midazolam.

Cette étude randomisée et à double insu réalisée chez 140 enfants (âgés de trois à douze ans) visait à déterminer si la clonidine orale administrée à la période préopératoire provoquait ou exagérait les vomissements postopératoires opérés pour strabisme. Les enfants étaient tous hospitalisés et ont été répartis aléatoirement entre quatre groupes ( $n=35$ par groupe): placebo (contrôle), diazepam $0,4 \mathrm{mg} \cdot \mathrm{kg}^{-1}$, clonidine $2 \mu \mathrm{g} \cdot \mathrm{kg}^{-1}$ et clonidine $4 \mu \mathrm{g} \cdot \mathrm{kg}^{-1}$. Ces produits ont été administrés 93-112 min (moyenne $100 \mathrm{~min}$ ) avant le moment anticipé de l'induction. La relaxation musculaire a été réalisée chez tous les patients avec du vécuronium et la curarisation résiduelle neutralisée avec de l'atropine et de la néastigmine avant l'extubation. On n'a administré ni morphinique ni d'antiémétique aux périodes pré- et pastopératoire. Tous les enfants sont demeurés deux jours à lhôpital après lopération. Lincidence et la fréquence des vomissements ont été comparées entre les groupe avec le test de Kruskall-Wallis Rank. La clonidine $4 \mu \mathrm{g} \cdot \mathrm{kg}^{-1}$ a provoqué une incidence et une fréquence inférieures à celles du placebo et du diazépam (incidence et fréquence: $11 \%$ et $1,37 \%$ et 3 , et $34 \%$ et 2 pour clonidine 4 $\mu \mathrm{g} \cdot \mathrm{kg}^{-1}$, placebo et diazépam respectivement; $P<0,05$ pour clonidine $4 \mu \mathrm{g} \cdot \mathrm{kg}^{-1}$ vs placebo et diazépam). Cependant, la clonidine à faible dose n'a pas eu d'effets. Ces données suggèrent que la clonidine en prémédication peut être efficace pour prévenir les vomissements après une intervention pour strabisme. La clonidine pourrait être supérieure aux autres prémédications telles que le diazépam et la midazolam.

Although clonidine, an $\alpha_{2}$-agonist, has been used as an effective premedicant in children, ${ }^{1,2}$ it is not clear whether it causes or is associated with an increased frequency of postoperative vomiting. In this study, we therefore intend to demonstrate the effect of oral clonidine premedication on this postoperative complication in children. The drug provides better preoperative sedation, attenuates car- 
diovascular responses to tracheal intubation compared with diazepam, and reduces anaesthetic requirement in children (in-patients). ${ }^{1,2}$ Clonidine is employed perioperatively in infants for its analgesic property. ${ }^{3}$ It has also been demonstrated to prolong the duration of analgesia by caudal bupivacaine. ${ }^{3}$

Some animal experiments indicate that clonidine administered systemically or intracerebroventricularly (icv) induces vomiting in a dose-dependent manner through a mechanism involving $\alpha_{2}$-adrenoceptors on the area postrema which contains the chemoreceptor trigger zone for vomiting and/or adjacent areas (dorsal motor nucleus of vagus). ${ }^{4}$ Although clonidine induces vomiting in humans who are not undergoing surgery, ${ }^{5}$ the drug has no effect on the incidence of postoperative vomiting in adults. ${ }^{6}$ However, no reports have been published on the effect of oral clonidine on postoperative emesis in children.

Children undergoing strabismus surgery have a high incidence of postoperative vomiting. The incidence of vomiting following strabismus correction in children who have not received prophylactic antiemetic treatment ranges from $40 \%$ to $85 \% .^{7-9}$ This experience is unpleasant for patients. Furthermore, vomiting may cause aspiration pneumonia and potentially dangerous dehydration. Many pharmacological interventions have been attempted to prevent this undesirable complication. ${ }^{-12}$

If the incidence of this unpleasant complication is increased in children receiving clonidine, this would be a very great disadvantage of clonidine used as a preanaesthetic medication, compared with other sedative premedicants (e.g., diazepam and midazolam). Diazepam and midazolam do not increase the incidence of postoperative emesis. ${ }^{13}$ Thus, we compared the effect of clonidine with that of diazepam which is routinely used in our hospital.

\section{Methods}

\section{Subjects and anaesthesia}

For this study, institutional approval was obtained from the Institutional Review Boand of Kobe University Hospital. For all children, informed consent was obtained from parents. We studied the effects of oral clonidine given as a preanaesthetic medication on postoperative emesis following strabismus surgery in 140 otherwise healthy children.

Inclusion criteria for the present study were: all subjects were in-patients and children aged 3-12 yr with ASA physical status 1. Patients with gastrointestinal disease, obese patients who were more than $20 \%$ heavier than their ideal body weight, those taking medication known to affect gastric fluid composition or gastric emptying, and those who had undergone any operation before were excluded. Using an envelope method, children were randomly assigned to one of four groups (35 children per group); placebo (control), diazepam $0.4 \mathrm{mg} \cdot \mathrm{kg}^{-1}$, clonidine $2 \mu \mathrm{g} \cdot \mathrm{kg}^{-1}$, or clonidine $4 \mu \mathrm{g} \cdot \mathrm{kg}^{-1}$ in $0.2 \mathrm{ml} \cdot \mathrm{kg}^{-1}$ apple juice. These agents were administered $100 \mathrm{~min}$ before the anticipated time of induction of anaesthesia. Table I indicates the demographic data of four groups. Diazepam at doses of $0.3-0.5 \mathrm{mg} \cdot \mathrm{kg}^{-1}$ is recommended for premedication to be given orally $60-120 \mathrm{~min}$ before anaesthesia. ${ }^{14,15}$ All the children also received atropine $0.03 \mathrm{mg} \cdot \mathrm{kg}^{-1}$ po in $0.15 \mathrm{ml} \cdot \mathrm{kg}^{-1}$ apple juice $60 \mathrm{~min}$ before the anticipated induction of anaesthesia.

Preoperative management was standardised. All children were prohibited from eating solid food or drinking milk products after midnight but were instructed to ingest a large volume of clear fluid $\left(10 \mathrm{ml} \cdot \mathrm{kg}^{-1}\right)$ three hours before induction of anaesthesia. All anaesthetics were standardised as follows: nitrous oxide $4 \mathrm{~L} \cdot \mathrm{min}^{-1}$, oxygen $2 \mathrm{~L} \cdot \min ^{-1}$, and halothane (up to $2.5 \%$ ), and $0.5-2.0 \%$ halothane and $60 \%$ nitrous oxide in oxygen were used for induction and maintenance of anaesthesia, respectively. Infusion was begun immediately after loss of consciousness was confirmed. Vecuronium bromide 0.1 $\mathrm{mg} \cdot \mathrm{kg}^{-1} \dot{\boldsymbol{w}}$ was then administered to facilitate tracheal intubation. All inductions were uneventful and no patients vomited during induction. Shortly after tracheal intubation, the gastric contents were aspirated via a 16Fr Argyle Salem Sump ${ }^{\circledR}$ tube, which was pulled out before tracheal extubation. All patients received diclofenac suppository 12.5 or $25 \mathrm{mg}$ after induction of anaesthesia for postoperative analgesia. No opioids were given throughout the study period. Intraoperative muscle relaxation was achieved with intermittent administration of vecuronium $0.02 \mathrm{mg} \cdot \mathrm{kg}^{-1}$, if necessary, to maintain $70 \%$ twitch depression monitored with TOF GUARD ${ }^{\circledR}$ (Biometer, Denmark). Following surgery, each patient's trachea was extubated in the operating room after residual neuromuscular blockade had been antagonized with neostigmine $0.05 \mathrm{mg} \cdot \mathrm{kg}^{-1}$ and atropine $0.02 \mathrm{mg} \cdot \mathrm{kg}^{-1}$. Criteria for extubation included (1) regular and adequate respiratory rate and depth of respiration; (2) an end-tidal $\mathrm{PCO}_{2}$ of $<50 \mathrm{mmHg}$; (3) fully reversed neuromuscular blockade (as assessed by sustained tetanic contraction with $50 \mathrm{~Hz}$ ); and (4) intact airway protective reflexes.

Postoperative recovery state was assessed using Aldrete score ${ }^{16}$ by an independent observer. This score was determined immediately after transfer to the ward (10-15 min after the end of anaesthesia). All the children were transferred directly to the opthalmological ward; the recovery room was not used in the present study. Supplemental diclofenac suppository was administered for postoperative pain when required by an observer blinded 
TABLE I Data of patients and surgery

\begin{tabular}{|c|c|c|c|c|}
\hline Groups & $\begin{array}{l}\text { Placebo } \\
\text { (control) }\end{array}$ & $\begin{array}{l}\text { Diazepam } \\
0.4 \mathrm{mg} \cdot \mathrm{kg}^{-1}\end{array}$ & $\begin{array}{l}\text { Clonidine } \\
2 \mu{ }^{-} k^{-I}\end{array}$ & $\begin{array}{l}\text { Clonidine } \\
4 \mathrm{\mu g} \cdot \mathrm{kg}^{-1}\end{array}$ \\
\hline$n$ & 35 & 35 & 35 & 35 \\
\hline $\operatorname{Sex}(M / F)$ & $13 / 22$ & $16 / 19$ & $15 / 20$ & $12 / 23$ \\
\hline Age $(y r)^{*}$ & $6.7 \pm 2.4$ & $6.7 \pm 2.6$ & $7.0 \pm 2.5$ & $6.6 \pm 2.5$ \\
\hline Weight $(\mathrm{kg})^{*}$ & $.23 \pm 7.8$ & $24 \pm 7.9$ & $25 \pm 8.2$ & $22 \pm 7.7$ \\
\hline \multicolumn{5}{|l|}{ Volume of clear fluids ingested } \\
\hline$\left(\mathrm{ml} \cdot \mathrm{kg}^{-1}\right)^{*}$ & $9.5 \pm 0.3$ & $9.5 \pm 0.4$ & $9.3 \pm 0.3$ & $9.7 \pm 0.4$ \\
\hline Anaesthesia time (min) & $97 \pm 23$ & $101 \pm 25$ & $96 \pm 23$ & $94 \pm 21$ \\
\hline Muscles repaired $\dagger$ & $2(1-4)$ & $2(2-4)$ & $2(2-4)$ & $2(1-4)$ \\
\hline
\end{tabular}

-Values are expressed as mean $\pm \mathrm{SD}$.

†Median (range).

At any variables, $P>0.05$.

TABLE II Incidence and frequency of postoperative emesis.

\begin{tabular}{lllll}
\hline Groups & $\begin{array}{l}\text { Placebo } \\
(\text { control) }\end{array}$ & $\begin{array}{l}\text { Diazepam } \\
0.4 \mathrm{mg} \cdot \mathrm{kg}^{-1}\end{array}$ & $\begin{array}{l}\text { Clonidine } \\
2 \mu g \cdot \mathrm{kg}^{-1}\end{array}$ & $\begin{array}{l}\text { Clonidine } \\
4 \mu g \cdot \mathrm{kg}^{-1}\end{array}$ \\
\hline Oral intake time (min) (mean $\pm \mathrm{SD})$ & $153 \pm 55$ & $159 \pm 58$ & $157 \pm 63$ & $171 \pm 65$ \\
Incidence & $13 / 35(37 \%)$ & $12 / 35(34 \%)$ & $10 / 35(29 \%)$ & $4 / 35(11 \%)^{* \dagger}$ \\
Frequency (median (range)) & $3(1-5)$ & $2(1-6)$ & $2(1-4)$ & $1(1) \pm \S$ \\
Recovery score (median (range)) & $9(6-10)$ & $9(6-10)$ & $9(6-10)$ & $8(6-10) \ddagger$ \\
\hline
\end{tabular}

$* P=0.012$ vs control group.

$\dagger P=0.046$ vs diazepam group.

$\ddagger P=0.010$ vs control group.

$\S P=0.015$ vs diazepam group.

to group assignment. Oral intake of clear fluid was allowed a minimum of one hour after surgery if the patients felt thirsty. Until then, the postoperative infusion was continued. Perioperative management of the children was performed by the same usual team of anaesthetists, ophthalmologists, and ward nurses.

\section{Data collection of emesis and statistics}

Time from the end of surgery to the first oral intake was recorded. Episodes of vomiting were recorded by the ward nurses, who were unaware of the nature of premedication. Retching and nausea were discounted, since these left no evidence. We did not use a nausea visual analogue scale, as it is not feasible for young children. No postoperative antiemetics were given. All the children were discharged from hospital two days after surgery without sequelae. Thus, it was possible to follow up all episodes of postoperative vomiting: the observation period in the present study was two days.

Statistical analysis was performed using analysis of variance for continuous variables (age, weight, volume of clear fluid ingested, anaesthesia time, and time to the first oral intake time) followed by multiple $t$ test with Bonferroni correction when indicated and using Kruskal-
Wallis Rank test, Fisher's exact test, and chi-squared test for discrete variables (gender, number of muscles repaired, Aldrete recovery score, and incidence and frequency of vomiting). Differences were considered statistically significant at $P<0.05$.

\section{Results}

Patients in the four groups were comparable with respect to age (3-12 yr), weight, fluid volume ingested, anaesthesia time, and the number of muscles repaired (Table I).

The time taken to oral fluid intake after surgery did not differ among the four groups (Table II). No children vomited before surgery, but vomiting occurred in all groups after operation. The overall incidence of vomiting was lower in the clonidine $4 \mu \mathrm{g} \cdot \mathrm{kg}^{-1}$ treated group (11\%) than in the control (37\%) and diazepam (34\%) groups (Table II). The incidence in the diazepam and clonidine $2 \mu \mathrm{g} \cdot \mathrm{kg}^{-1}$ groups (29\%) was similar to that in the control group ( $P=0.803$ for diazepam vs placebo and $P=$ 0.611 for clonidine $2 \mu \mathrm{g} \cdot \mathrm{kg}^{-1}$ vs placebo). Children receiving clonidine $4 \mu \mathrm{g} \cdot \mathrm{kg}^{-1}$ vomited less frequently (one time) than those receiving placebo ( $1-5$ times) or diazepam (1-6 times). The frequency in the diazepam and 
clonidine $2 \mu \mathrm{g} \cdot \mathrm{kg}^{-1}$ groups (1-4 times) was similar to that in the control group $(P=0.637$ for diazepam vs placebo and $P=0.051$ for clonidine $2 \mu \mathrm{g} \cdot \mathrm{kg}^{-1}$ vs placebo). All the children had recovered to the same degree on arrival in the ward $(P=0.967)$ (Table II).

\section{Discussion}

Although clonidine has been shown to induce vomiting in animals and humans, ${ }^{4,5}$ in this clinical study we demonstrated that oral clonidine in a dose of $4 \mu \mathrm{g} \cdot \mathrm{kg}^{-1}$ reduced the incidence of postoperative emesis in children undergoing strabismus surgery compared with diazepam $0.4 \mathrm{mg} \cdot \mathrm{kg}^{-1}$ or placebo. However, $2 \mu \mathrm{g} \cdot \mathrm{kg}^{-1}$ clonidine failed to do so. In anaesthetized and conscious cats, ${ }^{4,17}$ $i c v$ clonidine has been shown to elicit vomiting mediated by central $\alpha_{2}$-adrenoceptors on postsynaptic cells in the area postrema and/or extremely adjacent areas to the area postrema. Clonidine given icv at 10-30 $\mu$ g caused more frequent emesis in dogs than intravenous clonidine $11-100 \mu \mathrm{g} \cdot \mathrm{kg}^{-1} .{ }^{18}$ These animal findings are opposed of our observations in children. However, this discrepancy may be explained by unpublished findings that the peripheral administration of clonidine does not induce vomiting in cats. In a clinical study, clonidine $0.2-0.3 \mathrm{mg}$ (3-5 $\mu \mathrm{g} \cdot \mathrm{kg}^{-1}$ by estimate) seemed to decrease the incidence of postoperative vomiting in adults. ${ }^{6}$ However, this result was not conclusive because of the small sample size $(n=20$ each).

Postoperative vomiting is multifactorial in origin. During eye surgery, impulses from the extrinsic eye muscles are relayed to the vestibular nuclei via nuclei III, IV, and VI of the medial longitudinal fasciculi. ${ }^{10}$ The vestibular nuclei lie in the brainstem reticular formation and are closely associated anatomically with the vomiting centre. Postoperative vomiting during the early phase after strabismus surgery may be attributed to surgical stimulation of the sensory receptors of the eyes whereas vomiting in the late phase is thought to be motion sickness resulting from acute eye imbalance and diplopia (optokinetically induced motion sickness). ${ }^{10}$ Although the incidence of vomiting in our hospitals cannot be compared with that reported in other institutions because of differences in study protocols, we experienced a relatively lower incidence of postoperative vomiting even in children

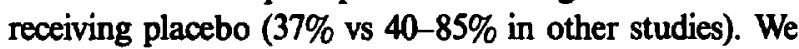
have no explanation for such differences. However, the low incidence of this postoperative complication in our institution may be related to our routine postoperative management, in particular, the long stay (two days) in hospital after strabismus surgery, which may lead children to postoperative restfulness. Our arbitrary assessment of postoperative rest revealed that restfulness was observed most frequently in children who received clonidine 4 $\mu \mathrm{g} \cdot \mathrm{kg}^{-1}$. This restfulness may contribute to the lowest incidence and frequency of postoperative vomiting in the high-dose clonidine group.

Many pharmacological interventions have attempted to decrease the incidence of this unpleasant complication, including lidocaine, ${ }^{10}$ droperidol,, 911 metoclopramide, ${ }^{12}$ and scopolamine. ${ }^{19}$ These drugs successfully reduce the incidence by $37-67 \%$. It is noteworthy that clonidine 4 $\mu \mathrm{g} \cdot \mathrm{kg}^{-1}$ elicited a $70 \%$ reduction in the incidence of vomiting. This antiemetic property of clonidine demonstrated in the current study may be unique to this special group (children undergoing strabismus surgery). The efficacy of the drug in other types of paediatric surgery deserves further study. Further studies are also required to examine whether clonidine premedication is effective for postoperative emesis in paediatric ambulatory strabismus surgery.

The safety of oral clonidine for children has been demonstrated in its use as a provocative growth hormone (GH) test to screen children for GH deficiency. ${ }^{20}$ The dosage used in this setting is $5 \mu \mathrm{g} \cdot \mathrm{kg}^{-1}$. A therapeutic use of clonidine at $75 \mu \mathrm{g} \cdot \mathrm{m}^{-2}$ for one year has been reported in 90 children with constitutional growth delay. ${ }^{21}$ These investigations appear to indicate the safety of clonidine for children at the dose used in the present study. Furthermore, an anecdotal report has revealed that there were no deaths in 11 toddlers ingesting clonidine accidentally in doses of $10-150 \mu \mathrm{g} \cdot \mathrm{kg}^{-1} .{ }^{22}$ This episode also relieves us of our anxiety that clonidine $4 \mu \mathrm{g} \cdot \mathrm{kg}^{-1}$ may have hazardous effects in children. However, further studies are required to verify the safety of premedication with oral clonidine before it can be routinely used for this purpose.

In conclusion, we have shown that preoperative oral clonidine at a dose of $4 \mu \mathrm{g} \cdot \mathrm{kg}^{-1}$ is associated with a reduced incidence of postoperative vomiting in children who have undergone strabismus surgery under general anaesthesia with halothane and nitrous oxide and received diclofenac for relief of postoperative pain. Our observations suggest that preanaesthetic medication with clonidine may be superior to that of other sedative premedicants (e.g., diazepam and midazolam) since most of these agents have no effect on the incidence of postoperative vomiting.

\section{References}

1 Mikawa K, Maekawa N, Nishina K, Takao Y, Yaku H, Obara $H$. Efficacy of oral clonidine premedication in children. Anesthesiology 1993; 79: 926-31.

2 Nishina $K$, Mikawa $K$, Maekawa N, Takao Y, Obara $H$. Clonidine decreases the dose of thiamylal required to induce anesthesia in children. Anesth Analg 1994; 79: 766-8. 3 Jamali S, Monin S, Begon C, Dubousset A-M, Ecoffey C. 
Clonidine in pediatric caudal anesthesia. Anesth Analg 1994; 78: 663-6.

4 Hikasa Y, Akiba T, Iino Y, Matsukura M, Takase K, Oga sawara $S$. Central $\alpha$-adrenoceptor subtypes involved in the emetic pathway in cats. Eur J Pharmacol 1992; 229: 241-51.

5 Houston MC. Clonidine hydrochloride: review of pharmacological and clinical aspects. Prog Candiovasc Dis 1981; 23: 337-50.

6 Carabine UA, Wright PMC, Moore J. Preanaesthetic medication with clonidine: a dose-response study. $\mathrm{Br} \mathbf{J}$ Anaesth 1991; 67: 79-83.

7 Hardy J-F, Charest J, Girouard G, Lepage Y. Nausea and vomiting after strabismus surgery in preschool children. Can Anaesth Soc J 1986; 33: 57-62.

8 Walsh C, Smith CE, Polomeno RC, Bevan JC. Postoperative vomiting following strabismus surgery in paediatric outpatients: spontaneous versus controlled ventilation. Can J Anaesth 1988; 35: 31-5.

9 Abramowitz MD, Oh TH, Epstein BS, Ruttimann UE, Friendly DS. The antiemetic effects of droperidol following outpatient strabismus surgery in children. Anesthesiology 1983; 59: 579-83.

10 Warner $L O$, Rogeres $M D$, Martino $L D$, Bremer $D L$, Beach $T P$. Intravenous lidocaine reduces the incidence of vomiting in children after surgery to correct strabismus. Anesthesiology 1988; 68: 618-21.

11 Lerman J, Eustis $S$, Smith DR. Effect of droperidol pretreatment on postanesthetic vomiting in children undergoing strabismus surgery. Anesthesiology 1986; 65: 322-5.

12 Broadman LM, Ceruzzi W, Patane PS, Hannallah RS, Ruttiman $U$, Friendly $D$ Metoclopramide reduces the incidence of vomiting following strabismus surgery in children. Anesthesiology 1990; 72: 245-8.

13 Parnis SJ, Foate JA, van der Wart JH, Short T, Crowe $C E$. Oral midazolam is an effective premedication for children having day-stay anaesthesia. Anaesth Intensive Care 1992; 20: 9-14.

14 Steward DJ. Psychological preparation and premedication. In: Gregory GA (Ed.). Pediatric Anesthesia, 2nd ed. New York: Churchill Livingstone Inc., 1989: 523-38.

15 Krane EJ, Davis PJ, Smith RM. Preoperative preparation. In: Motoyama EK (Ed.). Smith's Anesthesia for Infants and Children, 5th ed. St. Louis: CV Mosby, 1990: 201-16.

16 Aldrete $J A$, Kroulik $D$. A postanesthetic recovery score. Anesth Analg 1970; 49: 924-34.

17 Finch $L$. The cardiovascular effects of intraventricular clonidine and BAY 1470 in conscious hypertensive cats. $\mathrm{Br}$ J Pharmacol 1974; 52: 333-8.

18 Pickworth WB, Sharpe LG, Gupta VN. Morphine-like effects of clonidine on the EEG, slow wave sleep and behavior in the dog. Eur J Pharmacol 1982; 81: 551-7.
19 Horimoto Y, Tomie H, Hanazawa K, Nishida Y. Scopolmine patch reduces postoperative emesis in paediatric patients following strabismus surgery. Can J Anaesth 1991; 38: 441-4.

20 Wilson DM, Dotson RJN, Neely EK, Cohen P, Hintz RL, Rosenfeld $R G$. Effects of estrogen on growth hormone following clonidine stimulation. Am J Dis Child 1993; 147: 63-5.

21 Moreno Esteban B, Monereo Mejias S, Rodriguez PoyoGuerrero P, Moreno Esteban FJ, Tresguerres JAF. One year treatment with clonidine in children with constitutional growth delay. J Endocrinol Invest 1991; 14; 75-9.

22 Fiser DH, Moss MM, Walker W. Critical care for clonidine poisoning in toddlers. Crit Care Med 1990; 18: 1124-8. 